\title{
BRITISH TRAVELERS' IMPRESSIONS OF THE RUSSIANS DURING THE REIGN OF ALEXANDER II
}

\section{ВПЕЧАТЛЕНИЯ БРИТАНСКИХ ПУТЕШЕСТВЕННИКОВ О РУССКИХ ВО ВРЕМЕНА ПРАВЛЕНИЯ АЛЕКСАНДРА ІІ}

\author{
(C) 2016 г. I. Sakowicz \\ Uniwersytet Gdański Instytut Historii
}

Received: August 10, 2016

\begin{abstract}
Аннотация: Автор статьи анализирует наблюдения, касающиеся России и ее жителей, представленные британскими путешественниками в очерках и мемуарах времен Александра II (1855-1881). В действительности, немногие британцы посещали страну царей. Среди них мало кто владел русским языком. Русские высших сословий удивляли англичан западной внешностью, хорошими манерами и элегантностью. Однако преимущественно обобщения на тему русских рождались из наблюдений низов общества, прежде всего кучеров. Русские, по мнению путешественников, отличались коварством, рабским сознанием и леностью. Принятие самодержавия вытекало из славянской пассивности. Россия воспринималась как страна полуварварская и одновременно деспотическая. За 25 лет картина русского мира, созданная британскими путешественниками, не претерпела существенных изменений.

Ключевые слова: Россия, путешественники, путешествия, общественное мнение.

Abstract: This article examines the image of Russia and its people in the travelogues of British travelers during the rule of Alexander II (1855-1881). In reality, hardly anybody from Britain visited the country of the tsars, and very few could speak its language. The upper classes, mostly nobility, surprised English visitors with their Western European looks, good manners, and elegance. However, generalizations about Russians as a nation were based on the observations of lower classes, mostly coachmen. Russians in the opinion of the travelers were faithless, servile, and lazy. Slavonic passivity made them perfectly fit for the absolutist rule. Russia was perceived as a semi-barbaric and despotic country. Over the period of 25 years, there were no substantial changes in the travelers' descriptions of the country.
\end{abstract}

Keywords: Russia, travelers, travelogues, public opinion.

Information about the author: Iwona Sakowicz, Prof. UG, dr. hab. Uniwersytet Gdański Instytut Historii, Ul. Wita Stwosza 55, 80-952 Gdańsk. E-mail: I.Sakowicz@ug.edu.pl 
Russia was an unknown land for the majority of the British in the $19^{\text {th }}$ century. The Grand Tour which young and rich Englishmen took around Europe to finish their education, was largely centred on France, Germany or Italy. Eastern Europe together with Russia was practically excluded from this trip.

This does not mean that there were no visitors from England to the so-called Northern Empire. In the 1848 edition of a travel guide, Russia was featured only as part of the Handbook for Northern Europe; including Denmark, Norway, Sweden, Finland and Russia, but by 1865 , there appeared a volume devoted exclusively to Russia. The book was reprinted four times, in 1868, 1875, 1888, and 1893. Although this was still not much if compared, for example, with twelve editions of the Handbook for Travelers in Central Italy, this fact demonstrated increasing interest in the remote country that was by no means a popular tourist destination.

Political relations between Russia and Great Britain in the first part of the $19^{\text {th }}$ century varied from friendship during Napoleonic Wars to the strong Russophobia which led to the Crimean War. The reign of Alexander II (1855-1881) did not bring a significant breakthrough - relations were highly contingent on the mood of the moment and fluctuated from polite to occasionally bad. Nevertheless, despite occasional and apparent hostility, they never really turned belligerent.

Tsar Nicholas I, gendarme of Europe, was seen as an exemplary despot. His son and heir Alexander II taking the throne was perceived in Britain as a peaceful reformer. Russia seemed more open during his reign than during the previous stifling regime. Despite this, the travelers were not coming in large numbers since going to Russia was a real adventure. There are few travelogues of those travelers who visited the empire of Romanoff in the second part of the $19^{\text {th }}$ century, and only few of their authors could speak the language of the visited country. Donald Mackenzie Wallace and Henry Sutherland Edwards who both contributed to The Times at different points, were fluent in Russian and were accustomed to the way Russians thought. Herbert Barry who spent four years in Russia managing metallurgical enterprises could also understand some Russian. However, these three travelers were rather exceptional. An anonymous Englishwoman describing her ten years in Russia did not seem to be able to understand the language. Neither did other transient visitors: a politician Arthur Arnold, a novelist Selina Bunbury, and journalists Edward Dicey, Laurence Oliphant, and George Augustus Sala. The latter even compiled a very short vocabulary necessary for traveling in Russia: "na prava, na leva, pouyiama, stoi, pashol-skorei, shivai, dam na vodka, durak, sabakoutchelovek, tippian" [15, p. 103]. 
General knowledge about the country of the Tsars was also weak in Britain - there were but few articles in press or in published travelogues. Quite often the same authors were writing both. Some of the correspondence from Russia first appeared in the pages of periodical press before it was published in the book form. Dicey (Daily Telegraph), Sala (Household Words, Daily Telegraph), and Edwards and Wallace were publishing articles in periodicals using their first-hand knowledge of Russia.

It is important to note that British press had certain difficulties in obtaining political information from Russia in the $19^{\text {th }}$ century since none of the English newspapers placed a permanent correspondent there. Information was usually sent from Berlin and relied on Russian newspapers and official proclamations. Correspondents were sent to Russia during important political events such as celebrations of the royal family occasions - coronations or weddings. Due to the expanding circulation and low price, newspapers were available to wider sections of society and hence were very influential in creating public opinion.

Despite the existence of the abovementioned guidebook, general preconceptions about the country were simple: it was very distant, very cold, and its government was despotic. From the $16^{\text {th }}$ century's first visitors (Giles Fletcher, Jerome Horsey) to a famous nineteenth century traveler Marquise de Custine, Russians were described as barbarian and brutal Asians living in a backward, nearly mediaeval country [8; 6]. The iron rule of Tsar Nicholas I strengthened those notions.

Even British travelers found this general prejudice unfair. One of them articulated it overtly: "to Western Europe the Russian people are almost unknown, seldom awakening any interest and never meeting with any confidence or sympathy. Often judged of from absurd rumours, they are misunderstood, over-valued and not unfrequently feared. $<\ldots>$ This dread must be traced to the ambition of their government. But this is unfair" [18, p. 120]. Edward Dicey understood that a short visit was not sufficient to develop opinions about Russians as a nation: "It would be absurd for a man who has only been a couple of weeks in Russia to undertake to express any opinion about the national character" [9, p. 122]. It did not prevent him, however, from developing his own opinions.

British travelers describing Russians divided them into two groups: nobility and peasants. There was no middle class in Russia, a fact that astonished visitors from England and confirmed the oddity of the country and its people in the eyes of the former. The upper class - nobility - was charming, well educated, and fluent in foreign languages [9, p. 122; 19, p. 46]. Yet their external appearance was not convincing enough to the visitors. Dicey expressed certain feelings of distrust: "I have sometimes 
felt a passing doubt whether the Russian gentleman I have met with could possibly be so polished, so sensible and so liberal as I should suppose from their conversation." He admitted that the proverbial scratching (to see if there is a Tartar underneath) could solve the problem [9, p. 123]. Other travelers also felt superficiality of the civilized behavior of Russian upper classes. The noticeable anxious attempts on behalf of Russians to produce a good impression on foreigners had a completely different result [16, p. 32]. It led British travelers to perceive civilization in Russia as an external polish, artificial paint on the otherwise barbaric people [7, p. 381]. Herbert Barry left a scathing remark about Russian upper classes. They spoke a number of languages, bowed with grace but in reality were neither "manly" nor "earnest" [3, p. 106]. He also quoted a Russian professor: "Russian aristocracy have all the worst vices of the French grafted on to their native barbarism" [3, p. 115]. The anonymous Englishwoman noted that imitation of the "exterior polish of the French" by Russian nobles was not related to real civilization [17, p. 36].

The other Russian group discussed in travelogues were peasants. The British travelers hardly knew them. They described "moujiks" seen on the streets or employed as "ischvostchik" or "yamschik" [15, p. 102; 14, p. 122]. The general opinion shared by all visitors was that common people in Russia were extremely ignorant and superstitious [17, p. 152; 2, p. 30; 9, p. 231]. This allowed Edward Dicey to claim that "common people belonged to a lower grade of civilization" [9, p. 123]. The attitude of transient visitors looking for interesting characters is best manifested in the opinions of Selina Bunbury: she complained that superstitions of Russian people were not "poetic" [7, p. 161]. To Donald Mackenzie Wallace, who actually knew Russian peasants better than anybody else, they presented a perfect example of "primitive mankind" [19, p. 80]. Barry compared a peasant to the savage explaining that "mujik" is a thief who "takes what he wants because he is unable to understand the rights of the owner" [3, p. 140]. Russian common people were also compared to "overgrown children" [17, p. 198; 9, p. 231]. With childlike attitudes, peasants showed fear towards their superiors; "Of all authority he stands in awe $<\ldots>$ he approaches the master whose favour he would propitiate with the same homage that he pays in church $<\ldots>$ bending down and touching the ground with his forehead" wrote Selina Bunbury [7, p. 157]. Descriptions of peasants as big children afraid of their masters were anything but compliments. In Victorian England, manliness was the dominant ideal when it came to behaviour patterns, therefore comparison of peasants with children only confirmed their inferior status. A Russian peasant had other unpleasant traits as well: he was lazy, indolent, and dirty. It is important to note that neither Herbert Barry nor Henry Sutherland Edwards shared this opinion. They were familiar with Russian workers and highlighted 
positive traits of their character such as intelligence and skill [10, p. 387; 3, p. 133]. Barry even attributed all the negative traits of the Russian working class to an unfavourable political system [3, p. 124].

However, the descriptions of George Augustus Sala and Edward Dicey published earlier, in Household Words (1856) and the Daily Telegraph (1866), were read by many. For Sala, the whole appearance of common people, with their «oriental caftans, oriental beards and oriental dirt» was the proof of their non-European character [15, p. 102]. Dicey described indolent, lazy peasants working only fitfully, and dirty to an extent unknown in the West [9, p. 124]. "In many parts of the world you will see dirty people $<$... $>$ You must go to a Sclavonian nation to know what filth is in perfection" [9, p. 21].

British travelers, after a short time spent in Russia, started making generalizations about the national character of their hosts. Russians as a nation described by British travelers, did not reveal many positive qualities. Their appearance perhaps was the only thing about them favourably described: they were often featured as tall, strong, and good looking. Russian women, on the contrary, were considered rather plain; all the beauties were either of Circassian or Georgian origin; peasant women were generally described as hideous.

Russians were represented as "deceitful and their lack of honesty was immense" [17, p. 158]. George Augustus Sala writing for Dickens' weekly Household Words, compared Russians to Chinese. He claimed that both nations were "habitually false, thievish ... and faithless in diplomacy" [15, p. 172]. "There is a single difficulty at getting the truth" wrote Laurence Oliphant in 1853 [14, p. 64]. Similar complaint came later from Herbert Barry who had a first hand experience in contact with Russian workers [3, p. 135]. Some explained the failure to get true information from Russians by their bureaucratic system or long subjection to despotic rule [14, p. 64; 3 , p. 136]. After meeting the first honest Russian, Oliphant reported that the mere existence of this person actually confirmed the truth that "dishonesty is the rule in Russia" [14, p. 102].

In general, all the travelers were pleasantly surprised by friendliness and hospitality of Russian people. They claimed that kindness and courtesy were "instinctive" in them [9, p. 232; 17, p. 204]. Politeness was a singular trait of character regardless of social class. Common people were "exceedingly civil" and "polite" [3, p. 130]. These descriptions of naturally good-humoured simple people evoke an Enlightenment notion of "the age of nature" when a man lived in happy and innocent state before he was corrupted by society.

Russians, according to English travelers, had typical Slavonic character: they were passive but at the same time impulsive and impatient. The passiveness of their character made them susceptible to autocratic politi- 
cal system. Many travelers mentioned connections between Russian political system and national character. "Servility" and "slavish obsequiousness" mentioned by the anonymous Englishwoman as characteristic traits of the Russians were the consequences of long years of "bad" government [17, p. 94, 158, 174]. The authoress also expressed hope that Russians would become a "noble nation" under a better government [17, p. 173].

The general picture of Russians as a nation represented by British travelers was therefore unfavourable. Whether in regard to peasants or nobles, associations were the same; Russians were portrayed as primitive, backward, and half-civilized people. According to the Englishwoman, Russian were similar to the ancestors of the English and therefore were still at the level of civilization typical for the Middle Ages [17, p. 18].

One question that was often addressed was whether or not Russia was truly part of Europe. Travelogues often compared the Empire of Romanoffs to Asia. Edward Dicey spotted non-European influences in every corner of Russia. Peasants had non-European faces with broad foreheads, protuberant cheek-bones, sunken eyes, and flattened noses [9, p. 21]. For him, the environment too had Oriental aspect. Churches looked like mosques with "gilt minarets" [9, p. 12]. Dicey wrote that in Petersburg, Europe had conquered Asia but in Moscow the struggle was still undecided [9, p. 126]. The anonymous Englishwoman saw Moscow as a civilized city but claimed that the rest of the empire was barbarous [17, p. 33]. Although Wallace denounced "imaginative tourists" who see what they want, he and other travelers often compared Russian national character with Asiatic character. Fatalism and passivity were seen as decidedly Oriental traits inseparable from the character of the Middle East nations.

"Fatalism is perfect in Russia, everything is regarded as a matter of destiny," as Selina Bunbury complained [7, p. 166]. Laurence Oliphant also expressed his opinions about the "apathetic disposition" of Russian peasants [14, p. 153]. For a well organised Briton, the fact that "time is no object to a Russian" was surprising [14, p. 159]. Wallace, well accustomed to Russians, also wrote about "fatalism" and "fatalistic belief" prevalent in Russia [19, p. 5, 480]. He tried to explain that the apparent laziness and apathy of Russians is conspicuous when one travels from the West; for the traveler coming from the East, they seem energetic [19, p. 475].

Thus, the general opinion expressed by British travelers placed Russia closer to Asia than Europe. Despite European fashion seen on the streets of Petersburg or Moscow, there was a strong feeling of unfamiliarity and strangeness of this civilized veneer. Selina Bunbury called Russia an "unEuropean $<\ldots>$ half-Asiatic land" [7, p. 65]. Other travelers shared this view: "Muscovite civilization [is] more Asiatic than ours" [17, p. 309]. George Augustus Sala claimed that Russians were "outwardly polite, inwardly barbarous" and also emphasized their non-European status [15, 
p. 173]. The "indolence and incapacity of Russians" marked them as a barbarian nation [14, p. 141, 167]. Arthur Arnold traveling through Russia to Persia in the 1870 s openly stated that "Russians resemble those races whom we call Orientals" [2, p. 73].

Numerous suggestions of the barbarity and/or Asian character of Russians were common in the British press and in $19^{\text {th }}$ century travelogues. British strongly felt their superiority in comparison with Russia. They underlined the cultural difference between Great Britain, the leader among the civilized nations of Western Europe, and its barbarian imitator, Russia, capable but of following the example of others. Russia was quite an important element in developing the notion of Western identity as opposed to the barbarian East [1, p. 19]. Xenophobia was permanent in Victorian Britain [5, p. 215]. Industrial and commercial domination led to cultural arrogance. "Virulent Russophobia" remained a constant feature of Victorian public opinion [11, p. 8]. Travelers' opinions improved only in the $20^{\text {th }}$ century when the ties between Britain and Russia grew closer and cooperation in the political arena became a vital necessity for Albion [20, c. 36].

\section{REFERENCES}

1 Adamozsky E. Euro-orientalism: liberal ideology and the image of Russia in France (c. 1740-1880); Oxford: Peter Lang, 2006. 358 p.

2 Arnold A. Through Persia by caravan. London: Tinsley Brothers. 1877, $491 \mathrm{p}$.

3 Barry H. Russia in 1870. London: Wyman \& Sons, 1871. 418 p.

4 Blewitt $O$. Handbook for Travelers in Central Italy, including the Papal States, Rome, and the cities of Etruria. London: John Murary, 1843. 568 p.

5 Bolt C. Victorian Attitudes to Race. London: Routledge \& Kegan Paul; Toronto: Univ. of Toronto press, 1971. XVIII, $254 \mathrm{p}$.

6 Bond E.A., ed. Russia at the close of the sixteenth century. Comprising the treatise "Of the Russe Commonwealth," by Giles Fletcher and the travels of Sir Jerome Horsey, now for the first time printed entire from his own manuscript. London: T. Richards, 1856. 392 p.

7 Bunbury S. Russia after the War. The narrative of a visit to that country. London: Hurst \& Blackett, 1857. 385p.

8 Custine A. Russia. Abridged from the French. London: Longman, 1855. 532 p.

9 Dicey E. A Month in Russia During the Marriage of the Czarevitch. London: Macmillan and Co, 1867. 248 p.

10 Edwards H.S. The Russians at Home: unpolitical sketches. London: W. H. Allen and Co, 1861.432 p.

11 GardinerJ. The Victorians. An Age in Retrospect. London: Hambledon, 2002. 292 p.

12 Handbook for Northern Europe; including Denmark, Norway, Sweden, Finland, and Russia. London: John Murray, 1848. 637 p.

13 Handbook for Travelers in Russia, Poland, and Finland. London: John Murray, 1865. 282 p. 
14 Oliphant L. The Russian Shores of the Black Sea and A Journey to Katmandu. Köln: Könemann, 1998. 486 p.

15 Sala G.A. A Journey due North; Being Notes of a Residence in Russia in the Summer of 1856. London: Richard Bentley, 1859. 378 p.

16 Sheil M.L. Glimpses of Life and Manners in Persia. With notes on Russia, Koords, Toorkomans, Nestorians, Khiva and Persia. London: John Murray, 1856. 402 p.

17 The Englishwoman in Russia: Impressions of the Society and Manners of the Russians at home. By a Lady ten years resident in that country. London: J. Murray, 1855. 350 p.

18 Tilley H. A. Eastern Europe and Western Asia: political and social sketches on Russia, Greece, and Syria in 1861-2-3. London: Longman, 1864. 374 p.

19 Wallace D. M. Russia. New York, Henry Holt and Company, 1905. 672 p.

20 Зашихин А. Н. Глядя из Лондона. Россия в общественной мысли Британии второй половины XIX - начала XX века. Архангельск: Изд-во Поморского межд. пед. ун-та, 1994. 208 c. - Zashikhin A. N. Glyadya iz Londona. Rossia v obshestvennoi musli Britanii vtoroi polovini XIX - nachala XX veka [Looking from out of London. Russia in British social thought, second half of the $19^{\text {th }}$ - beginning of the $20^{\text {th }}$ centuries]. Archangelsk, Izd-vo Pomororskogo mezhd. ped. un-ta Publ., 1994. 208 p. 